\title{
沖縄島およびその近海離島における福木屋敷林の地域特性 A STUDY OF PHYSICAL CHARACTERISTICS OF PREMISES FOREST ON OKINAWA ISLAND AND ITS NEIGHBORING ISLANDS
}

\author{
安藤徹哉*, 小野啓子**, 凌敏*** \\ Tetsuya ANDO, Keiko ONO and Min LING
}

\begin{abstract}
Although yashikirin(premises forest) of fukugi (Garcinia subelliptica) trees were common in Okinawa before World War Two, there are only a handful of villages that retain the traditional landscape of fukugi trees today. This study analyses the physical characteristics of yashikirin in Imadomari Village, Nakijin on Okinawa Island and Tonaki Village on Tonaki Island to compare them with yashikirin in Bise Village, Motobu on Okinawa Island and Higashi and Nishi Villages on Aguni Island. Through comparing the physical features of yashikirin in each village, it can be concluded that the trees have been planted in correspondense with the microclimates of each location, particularly to withstand the srtong winds during the winter months. The results of the study also suggest that the historical development of the villages can be traced through the locations of older trees. Although Bise and Tonaki are better known as locations with fukugi yashikirin, Higashi and Nishi on Aguni and Imadomari are also worthy of mention as older trees can be found in these areas.
\end{abstract}

Keywords: Okinawa, village landscape, fukugi trees, premises forest

沖縄、集落景観、福木、屋敷林

\section{1. はじめに}

戦後、急速な近代化が進んだ沖縄において、福木屋敷林に囲まれ た伝統的景観を残寸集落は貴重な存在となっている。琉球王府は家 屋や畑を守るため、18 世紀頃から屋敷林として福木 ${ }^{\text {注 } 1)}$ の植樹を奨励 したとされる注2)。戦前までの琉球諸島では、こうした屋敷林が生活 空間として重要な役割を果たしていたが、第二次大戦後の米軍によ る土地の強制収用や生活の近代化に伴い、その大半が伐採され姿を

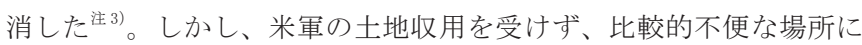
位置していたため近代化の影響を受けにくかった集落の中には、福 木屋敷林が面的な広がりを見せる事例が残っている。その代表的な 事例として、八重山諸島では波照間（はてるま）島、宮古諸島では 多良間（たらま）島、沖縄島では北部の本部（もとぶ）町備瀬（びせ） 集落と今帰仁（なきじん）村今泊（いまどまり）集落、沖縄島近海 の離島（以下、近海離島とする）では栗国（あぐに）島、渡名喜（と なき）島、伊是名（いぜな）島などをあげることができる。

そうした事例の内、筆者らはこれまで備瀬集落注4) と粟国島東・西 集落注5) を対象として、集落単位での福木屋敷林の実態を調査分析し てきた。本研究は、複数の集落の福木屋敷林を比較検討寸ることに より、その地域特性を明らかにすることを目的としている。研究対 象とする集落は、これまで調查した集落との地理的な近接性を考慮 し、沖縄島の備瀬集落とその北に位置する今泊集落、近海離島の粟
国島東・西集落とその南に位置する渡名喜島渡名喜集落を選定した ( 図 1)。まず、今泊集落と渡名喜集落の福木屋敷林の実態を調查分 析した後、備瀬集落と粟国島東・西集落を加えた 4 集落の福木屋敷 林の比較検討を行なう。

沖縄の福木屋敷林に関する既往文献としては、やまびこの会編の 『沖縄のフクギ（福木）屋敷林を考える』(2006) 注6) がある。また、 今泊集落の福木屋敷林に関連する既往文献としては、今泊誌編集委 員会編の『今泊誌』(1994）注7)、今帰仁村教育委員会編の『今帰仁 村文化財調查報告書第 25 集』(2008) 注8) などがある。さらに、渡名 喜島の福木屋敷林に関連する既往文献としては、古川・山田・大塚

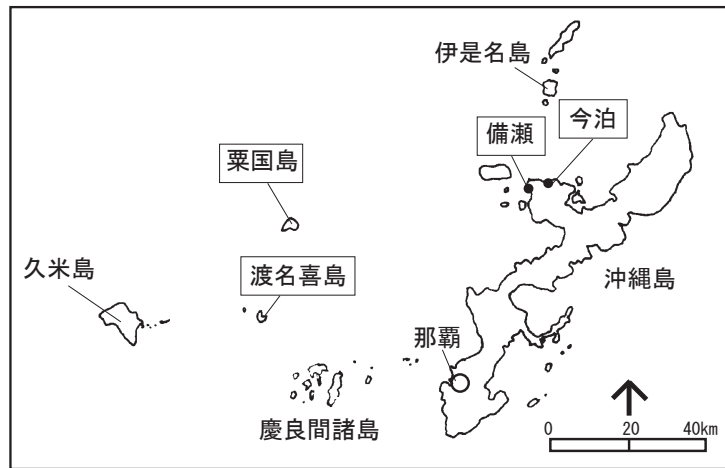

図 1 対象集落の位置

\footnotetext{
* 琉球大学工学部環境建設工学科 准教授 ·博士 (工学)

Assoc. Prof., Dept. of Civil Engineering and Architecture, University of the Ryukyus, Dr. Eng.

** 沖縄大学法経学部法経学科 教授·博士(建築学)

*** 河北農業大学植物保護学院 修士 (工学)
} 
による『沖縄・渡名喜島における集落の風性状について：その 1 実 測調查による解析』(1985) ${ }^{\text {注9) }}$ と『沖縄・渡名喜島における集落の 風性状について：その 2 風洞実験による解析』(1985) 注 10$)$ 、渡名喜 島調查委員会編の『沖縄渡名喜島における言語・文化の総合的研究』 (1991) 注 11)、神末・森田・渡嘉敷による『沖縄の小離島における防 風植栽空間に関する考察』(1996) ${ }^{\text {注 }}{ }^{12}$ 、大石・大戸による『小離島 におけるフクギ屋敷林の環境特性に関する研究』(1996) 注13)、漆原・ 乙幡による『沖縄県渡名喜島における屋敷囲いの特色とその変遷』 (2007) 注 14) などがある。しかしこれまで、今泊集落と渡名喜集落の 個々の福木の幹回りを計測して屋敷林の構成を定量的に明らかにす るような研究や、複数の集落の比較を通して福木屋敷林の地域特性 を明らかにするような研究は行なわれていない。

\section{2. 今帰仁村今泊集落における福木屋敷林の実態}

今帰仁村今泊集落は、那覇市の北約 $80 \mathrm{~km}$ の本部半島北端に位置す る人口 956 人 $(2009$ 年 3 月現在）の集落である（図 1)。集落の南側 は今帰仁城趾へと連なる山間部となっており、北側の海岸線沿いの 平坦な土地に比較的密集した集落を形成している。1973 年（沖縄の 本土復帰の翌年 ) に今帰仁原と親泊原が合併して今泊集落となった。 今帰仁原（なきじんばる）、親泊原（おやどまりばる）共に、今帰仁 城の近くから移動してきたと伝えられている注 15)。現地調查は、2008 年 5 月 3 日から 5 日にかけて実施した。

\section{1 今泊集落における福木屋敷林の特徵}

\subsection{1 幹回り別の福木の本数}

今泊集落内の寸心゙ての福木の幹回り（地表から $1.3 \mathrm{~m}$ の高さ）を $10 \mathrm{~cm}$ 刻夕の印をつけた紐と目視により計測した ${ }^{\text {12 }}{ }^{16)}$ 。その結果、集 落全体 (260 区画) で合計 9, 904 本の福木を確認することができた（表 1)。1 区画あたりの福木の本数は、38.1 本となる (表 2)。
福木の幹回りを「太い」 $(50 \mathrm{~cm}$ 以上 )、「中間」 $(20 \mathrm{~cm}$ 以上 $50 \mathrm{~cm}$ 未 満 )、「細い」 $(20 \mathrm{~cm}$ 未満 $)$ に 3 区分すると注 17$) 、$ 幹回りの構成は、「太 い」 $31.7 \%$ 、「中間」 $36.7 \%$ 、「細い」 $32.1 \%$ となる（表 3)。

\section{1.2 屋敷林密度の分布特性}

区画の四周を東側辺、西側辺、南側辺、北側辺に分け、辺ごとの 福木の幹断面積の総和を辺長で除した值を屋敷林密度とする注 18$)$ 。 屋敷林密度が 5 以上をランク $6 、 4$ 以上 5 未満をランク $5 、 3$ 以上 4 未満をランク $4 、 2$ 以上 3 未満をランク $3 、 1$ 以上 2 未満をランク 2 とし、 0 以上 1 未満は 0 のみをランク 0 、それ以外はランク 1 とする。 さらに、ランク 0 を無屋敷林辺、ランク $1 、 2 、 3$ の和を低密度辺、 ランク 4、5、6の和を高密度辺とした。

隣接する区画では屋敷林は戸境上に植えられ、隣家同士で共有さ れる。今泊集落全 260 区画の総辺数は 1,040 辺となるが、戸境上の 屋敷林は 136 辺 (13.1\%) に過ぎなかった。このため全体に対する影 響は大きくないと判断し、戸境上の屋敷林は重複してカウントした。

集落全体の平均屋敷林密度は、1.03 となる (表 4)。屋敷林密度の 構成は、高密度辺 $10.5 \%$ 、低密度辺 $47.5 \%$ 、無屋敷林辺 $42.0 \%$ と なる（表 5)。区画の四周に福木が一本も見られない無屋敷林区画の 割合は、全体の $10.4 \%$ であった（表 6)。地区別の無屋敷林区画の割 合は、今帰仁原地区 $9.1 \%$ 、親泊原地区 $10.8 \%$ となり、親泊原地区 の方がやや高い。無屋敷林区画は、集落北端の臨海部と南端の国道 505 号線沿いに多く見られる(図2)。

集落内の地区別の福木の本数は、今帰仁原地区 3,771 本、親泊 原地区 6,133 本であり、1 区画あたりの本数はそれぞれ、 57.1 本、 31.6 本となる (表 2)。平均屋敷林密度は、今帰仁原地区 (1.31)の 方が親泊原地区 (0.90) よりも高い（表 4)。また、無屋敷林辺の 割合は、親泊原地区 (45. 4\%) の方が今帰仁原 $(32.2 \%)$ よりも高く、 高密度辺の割合は逆に、今帰仁原地区 $(16.7 \%)$ の方が親泊原地区

表 1 今泊集落の幹回り別の福木の本数

\begin{tabular}{|c|c|c|c|c|c|c|c|c|c|c|c|c|c|c|c|c|c|c|c|c|c|c|c|c|c|c|c|c|c|c|c|}
\hline $\begin{array}{c}\text { 幹回り) } \\
\text { (cm) }\end{array}$ & -20 & $\begin{array}{l}20- \\
30 \\
\end{array}$ & $\begin{array}{l}30- \\
40\end{array}$ & $\begin{array}{l}40- \\
50 \\
\end{array}$ & $\begin{array}{l}50- \\
60\end{array}$ & $\begin{array}{c}60- \\
70 \\
70\end{array}$ & $\begin{array}{l}70- \\
80 \\
\end{array}$ & $\begin{array}{l}80- \\
90\end{array}$ & \begin{tabular}{l|l|}
$90-$ & 1 \\
100 & \\
\end{tabular} & \begin{tabular}{|c|c|c|}
$100-$ & 1 \\
110
\end{tabular} & $\begin{array}{l}110- \\
120 \\
\end{array}$ & $\begin{array}{l}120- \\
130\end{array}$ & $\begin{array}{l}130- \\
140 \\
\end{array}$ & $\begin{array}{l}140- \\
150\end{array}$ & \begin{tabular}{|c|c|c|}
$150-$ & 1 \\
160
\end{tabular} & \begin{tabular}{|c|}
$60-$ \\
170 \\
\end{tabular} & $\begin{array}{c}170- \\
180\end{array}$ & $\begin{array}{l}180- \\
190 \\
\end{array}$ & $\begin{array}{l}190- \\
200\end{array}$ & $\begin{array}{c}200- \\
210 \\
\end{array}$ & \begin{tabular}{r|l}
210 & 22 \\
-22 & 2 \\
\end{tabular} & $\begin{array}{l}220- \\
230 \\
230\end{array}$ & \begin{tabular}{|l}
$230-$ \\
240
\end{tabular} & \begin{tabular}{|l|}
$240-$ \\
250
\end{tabular} & \begin{tabular}{|l}
$250-$ \\
260
\end{tabular} & \begin{tabular}{|c|c|}
$260-$ \\
270
\end{tabular} & \begin{tabular}{|c|}
$270-$ \\
280 \\
\end{tabular} & $\begin{array}{l}280- \\
290\end{array}$ & $\begin{array}{r}290- \\
300\end{array}$ & $300-$ & 合計 \\
\hline 今門仁原 & 1,017 & 418 & 334 & 281 & 351 & 242 & 267 & 219 & 217 & 252 & 27 & \begin{tabular}{|l|}
95 \\
\end{tabular} & \begin{tabular}{|c|}
13 \\
\end{tabular} & & & & & & & & & 0 & & $\begin{array}{ll}0 \\
\end{array}$ & 0 & & 0 & & & 0 & 3,771 \\
\hline 親泊原 & 2,168 & 701 & 627 & 448 & 422 & 350 & 282 & 303 & 237 & 214 & 102 & 129 & 30 & 33 & 17 & 17 & 6 & 11 & 4 & 9 & & 2 & & 3 & 5 & & 0 & 0 & & & 6,133 \\
\hline & 3.185 & 119 & 961 & & & & & & & & 129 & 224 & & & & & & & & & & & & & & & & & & & \\
\hline
\end{tabular}

表 2 今泊集落の区画あたり福木の本数表 3 今泊集落の幹回り 3 区分別の福木の本数

\begin{tabular}{|l|c|r|r|}
\hline & \multicolumn{1}{|c|}{ 本数 } & \multicolumn{1}{|c|}{ 区画数 } & 本数 $/$ 区画 \\
\hline 今帰仁原 & 3,771 & 66 & 57.1 \\
\hline 親泊原 & 6,133 & 194 & 31.6 \\
\hline 今泊 & 9,904 & 260 & 38.1 \\
\hline
\end{tabular}

\begin{tabular}{|c|r|r|r|r|r|r|r|}
\hline \multicolumn{2}{|c|}{ 今幹回り } & \multicolumn{2}{|c|}{ 今帰仁原 } & \multicolumn{2}{|c|}{ 親泊原 } & \multicolumn{2}{|c|}{ 今泊 } \\
\hline 太い & $50 \mathrm{~cm}$ 以上 & 1,017 & $27.0 \%$ & 2,189 & $35.7 \%$ & 3,137 & $31.7 \%$ \\
\hline 中間 & $20 \mathrm{~cm}$ 以上 $50 \mathrm{~cm}$ 未満 & 1,033 & $27.4 \%$ & 1,776 & $29.0 \%$ & 3,582 & $36.2 \%$ \\
\hline 細い & $20 \mathrm{~cm}$ 未満 & 1,721 & $45.6 \%$ & 2,168 & $35.3 \%$ & 3,185 & $32.1 \%$ \\
\hline 合計 & 3,771 & $100.0 \%$ & 6,133 & $100.0 \%$ & 9,904 & $100.0 \%$ \\
\hline
\end{tabular}

表 4 今泊集落の平均屋敷林密度

\begin{tabular}{|l|r|r|r|}
\hline & 親泊原 & 今帰仁原 & 今泊 \\
\hline 東側辺 & 0.99 & 1.37 & 1.11 \\
\hline 西側辺 & 0.85 & 1.38 & 1.01 \\
\hline 南側辺 & 0.75 & 0.90 & 0.80 \\
\hline 北側辺 & 1.01 & 1.65 & 1.21 \\
\hline 全体 & 0.90 & 1.31 & 1.03 \\
\hline
\end{tabular}

表 5 今泊集落の屋敷林密度の構成

\begin{tabular}{|c|c|c|c|c|c|c|c|c|}
\hline \multirow{3}{*}{ ランク } & \begin{tabular}{|l} 
無屋敷林辺 \\
\end{tabular} & \multicolumn{3}{|c|}{ 低密度辺 } & \multicolumn{3}{|c|}{ 高密度辺 } & \multirow{3}{*}{ 合計 } \\
\hline & - & $\ldots$ & $\ldots 2 \ldots$ & _. 3 & -4 & $\ldots$ & 6. & \\
\hline & (0) & $\begin{array}{l}\text { (0を超え } \\
\text { て1未満) }\end{array}$ & $\begin{array}{l}\text { (1以上2 } \\
\text { 末満) }\end{array}$ & $\begin{array}{l}\text { (2以上 } \\
\text { 3未満) }\end{array}$ & $\begin{array}{l}\text { (3以上 } \\
\text { 4末満) }\end{array}$ & $\begin{array}{l}\text { (4以上5 } \\
\text { 未満) }\end{array}$ & (5以上) & \\
\hline \multirow[t]{3}{*}{ 今帰仁原 } & 85 & 60 & 51 & 24 & 25 & & & 264 \\
\hline & $32.2 \%$ & $22.7 \%$ & $19.3 \%$ & $9.1 \%$ & $9.5 \%$ & $3.4 \%$ & $3.8 \%$ & $100.0 \%$ \\
\hline & & & $51.1 \%$ & & & $16.7 \%$ & & \\
\hline \multirow[t]{3}{*}{ 親泊原 } & 352 & 171 & $\begin{array}{r}114 \\
\ldots\end{array}$ & 74 & $\begin{array}{r}40 \\
-\end{array}$ & 10 & -15 & $\begin{array}{r}776 \\
\ldots\end{array}$ \\
\hline & $45.4 \%$ & $22.0 \%$ & $14.7 \%$ & 9.50 & $5.2 \%$ & $1.3 \%$ & $1.9 \%$ & $100.0 \%$ \\
\hline & & & $46.2 \%$ & & & $8.4 \%$ & & \\
\hline \multirow[t]{3}{*}{ 今泊 } & 437 & 231 & 165 & -98 & 65 & 19 & $\ldots 25$ & 1,040 \\
\hline & $42.0 \%$ & $22.2 \%$ & $15.9 \%$ & 9.40 & $6.3 \%$ & $1.8 \%$ & $2.4 \overline{\%}$ & $100.0 \%$ \\
\hline & & & $47.5 \%$ & & & $10.5 \%$ & & \\
\hline \multicolumn{9}{|c|}{ 表 6 今泊集落の無屋敷林区画の状況 } \\
\hline & |区画数 無 & 屋敷林区画 & 数|無屋㳀 & 效林区百 & 武比率 & & & \\
\hline 今帰仁原 & 66 & & 6 & & 9. $1 \%$ & & & \\
\hline 親泊原 & 194 & & 21 & & $10.8 \%$ & & & \\
\hline 今泊 & 260 & & 27 & & $10.4 \%$ & & & \\
\hline
\end{tabular}

表 7 今泊集落の方位別の屋敷林密度の構成

\begin{tabular}{|c|c|c|c|c|c|c|c|c|}
\hline \multirow{3}{*}{ ランク } & 無屋敷林辺 & \multicolumn{3}{|c|}{ 低密度辺 } & \multicolumn{3}{|c|}{ 高密度辺 } & \multirow{3}{*}{ 合計 } \\
\hline & 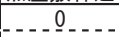 & & $-\ldots$ & 3 & $-{ }_{-1} \ldots$ & -5 & 6 & \\
\hline & (0) & $\begin{array}{l}\text { (0を超ええ } \\
\text { て1末満) }\end{array}$ & $\begin{array}{l}\text { (1以上2 } 2 \\
\text { 未満) }\end{array}$ & $\begin{array}{l}(2 以 5 \\
3 \text { 未満) }\end{array}$ & $\begin{array}{l}\text { (3以下 } \\
4 \text { 未満) }\end{array}$ & 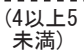 & (5以上) & \\
\hline \multirow[t]{3}{*}{ 東側辺 } & \multirow{3}{*}{$\begin{array}{r}-108 \\
41 .-5 \%\end{array}$} & 49 & 46 & 29 & 16 & & & \multirow{3}{*}{$\begin{array}{r}-260 \\
100 \\
-0 \%\end{array}$} \\
\hline & & $18.8 \%$ & $17.7 \%$ & $11.2 \%$ & $6.1 \%$ & $1.2 \%$ & $3.5 \%$ & \\
\hline & & & $47.7 \%$ & & & $10.8 \%$ & & \\
\hline \multirow[t]{2}{*}{ 西側辺 } & \multirow[t]{2}{*}{$-\frac{110}{32}$} & 21.97 & $\begin{array}{r}-40 \\
-15.4 \%\end{array}$ & $\begin{array}{r}-26 \\
-10.0 \% \\
\end{array}$ & $\begin{array}{c}-17 \\
-6.5 \% \\
\end{array}$ & & $2.7 \frac{1}{4}$ & \multirow[t]{2}{*}{$100=\frac{260}{0}$} \\
\hline & & & $47.3 \%$ & & & $10.4 \%$ & & \\
\hline \multirow[t]{3}{*}{ 南側辺 } & \multirow{3}{*}{$\begin{array}{r}-117 \\
-45.0 \%\end{array}$} & 71 & $\ldots 35$ & - 18 & 12 & $\ldots 4$ & $-\underline{3}$ & \multirow{3}{*}{$\begin{array}{c}-260 \\
-100 \\
-0.0 \%\end{array}$} \\
\hline & & $27.3 \%$ & $13.5 \%$ & $6.9 \%$ & $4.6 \%$ & $1.5 \%$ & $1.2 \%$ & \\
\hline & & & 47. $7 \%$ & & & 7. $3 \%$ & & \\
\hline \multirow[t]{3}{*}{ 北側辺 } & \multirow{3}{*}{$\begin{array}{r}-102 \\
39.2 \%\end{array}$} & 54 & ... 44 & $-\ldots 25$ & 19 & $\ldots$ & $\ldots-7$ & \multirow{3}{*}{$\begin{array}{c}-260 \\
-\quad-00\end{array}$} \\
\hline & & $20.8 \%$ & 16. $9 \%$ & $9.6 \%$ & 7. $3 \%$ & $3.5 \%$ & $2.7 \%$ & \\
\hline & & & $47.3 \%$ & & & $13.5 \%$ & & \\
\hline \multirow[t]{3}{*}{ 全体 } & \multirow{3}{*}{$\begin{array}{r}-437 \\
42.0 \%\end{array}$} & 231 & $\ldots$ & 98 & 64 & $\ldots 19$ & $2 \underline{2}$ & 1,040 \\
\hline & & 22. $2 \%$ & $15.9 \%$ & 9. $4 \%$ & 6. $2 \%$ & $1.8 \%$ & $2.5 \%$ & \multirow{2}{*}{$100.0 \%$} \\
\hline & & & 47. $5 \%$ & & & $10.5 \%$ & & \\
\hline
\end{tabular}


(8. 4\%) よりも高い（表 5)。これらのことから、親泊原地区よりも 今帰仁原地区の福木屋敷林の方が充実していることが分かる。

\subsection{3 方位と屋敷林密度の関係}

次に、方位と屋敷林密度の関係を見ていく。今泊集落における方 位別の平均屋敷林密度は、高い順に北側 (1.21)、東側 (1.11)、西側 （1.01）、南側（0.80）となる（表 4)。また、方位別の屋敷林密度の 構成を見ると、無屋敷林辺の割合は高い順に、南側 $(45.0 \%)$ 、西側 $(42.3 \%)$ 、東側 $(41.5 \%)$ 、北側 $(39.2 \%)$ となり、高密度辺の割合は逆に、 北側 $(13.5 \%)$ 、東側 $(10.8 \%)$ 、西側 $(10.4 \%)$ 、南側 $(7.3 \%)$ の順となる（表 7)。これらのことから、今泊集落の福木屋敷林は区画の北側が最も 充実しており、東側（さらに僅差で西側）がそれに次ぐ構成となっ ていることが分かる。

今帰仁村には気象庁の測候地点がないため、名護市のアメダス データ（2006-2008）を参考にすると、6月から 8 月は南東〜南西の風、 9 月から 5 月は北〜北北東の風が多い（表 8)。また、沖縄地方では、 台風の接近時に東風が吹き、通過後には西風に変わる。今泊集落は、
東シナ海に突き出した小さな岬状の土地に立地している。このため、 冬期には北側から季節風が吹き続け、台風時には北に加えて東西方 向からも潮風が吹きつける。今泊集落の福木屋敷林の構成は、こう した周辺環境にうまく対応している。

\section{2 大福木の分布と集落形成の関係}

今泊集落はそのほぼ全域が基盤状の道路構成をしているが、これ は今から約 270 年前に導入された地割土地制度注 19$)$ に基づくもので ある。

福木の幹回りからその樹齢を推定すると衤20)、幹回り $300 \mathrm{~cm}$ の福 木の樹齢は約 383 年となり、地割土地制度が導入されるよりも 100 年以上前に植樹されたと考えられる。幹回り $200 \mathrm{~cm}$ の福木の推定樹 齢は約 255 年であり、地割土地制度の導入と時期的にほぼ一致する。 幹回り $100 \mathrm{~cm}$ の福木の推定樹齢は約 128 年であり、1879 年の沖縄県 設置（いわゆる琉球処分）とほぼ一致する注21)。

そこで、沖縄県設置以前に植樹されたと考えられる幹回り $100 \mathrm{~cm}$ 以上の福木を大福木とし、その幹回りを $300 \mathrm{~cm}$ 以上、 $200 \mathrm{~cm}$ 以上

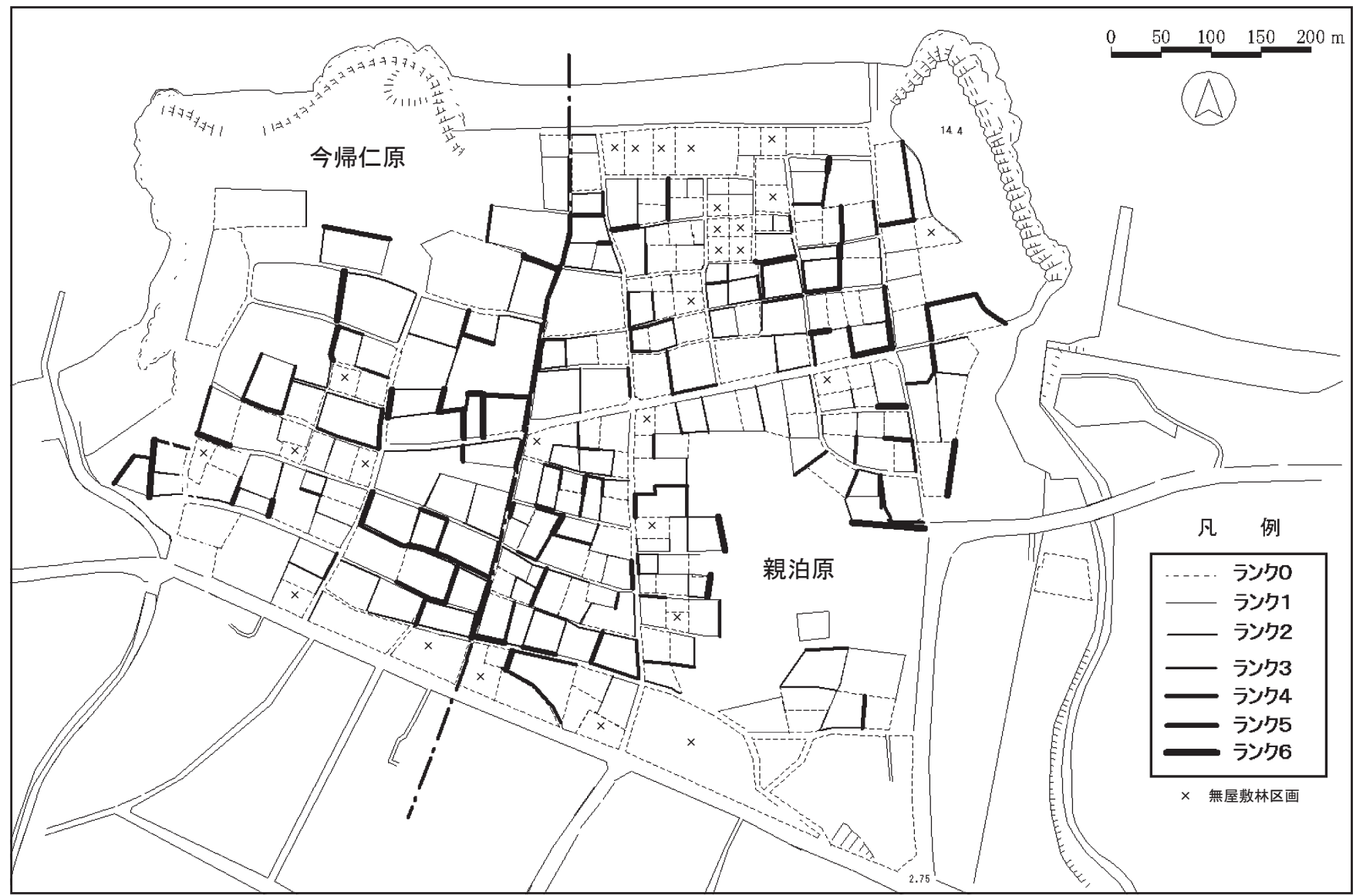

図 2 今泊集落の屋敷林密度および無屋敷林区画の分布

表 8 名護市の月ごとの最多風向（2006-2008）

\begin{tabular}{|c|c|c|c|}
\hline & 2006 & 2007 & 2008 \\
\hline 1月 & 北 & 北北東 & 北北東 \\
\hline 2月 & 北北東 & 北北東 & 北 \\
\hline 3月 & 北 & 北 & 北北東 \\
\hline 4月 & 北北東 & 北北東 & 北北東 \\
\hline 5月 & 南南東 & 北北東 & 北北東 \\
\hline 6月 & 南 & 南南西 & 南 \\
\hline 7月 & 南南東 & 南西 & 南東 \\
\hline 8月 & 南東 & 東南東 & 南南西 \\
\hline 9月 & 北北東 & 北北東 & 南東 \\
\hline 10月 & 北北東 & 北北東 & 北北東 \\
\hline 11月 & 北北東 & 北北東 & 北北東 \\
\hline 12月 & 北 & 北北東 & 北北東 \\
\hline
\end{tabular}

表 9 今泊集落の幹回り $100 \mathrm{~cm}$ 以上の 大福木の本数

\begin{tabular}{|c|r|r|r|}
\hline 幹回り & $\begin{array}{c}100 \mathrm{~cm} \\
\text { 未満 }\end{array}$ & $\begin{array}{c}100 \mathrm{~cm} \\
\text { 以上 }\end{array}$ & \multicolumn{1}{c|}{ 合計 } \\
\hline 今帰仁原 & 3,346 & 425 & 3,771 \\
& $88.7 \%$ & $11.3 \%$ & $100.0 \%$ \\
\hline 親泊原 & 5,538 & 595 & 6,133 \\
& $90.3 \%$ & $9.7 \%$ & $100.0 \%$ \\
\hline 今泊 & 8,884 & 1.020 & 9,904 \\
& $89.7 \%$ & $10.3 \%$ & $100.0 \%$ \\
\hline
\end{tabular}

表 10 今泊集落の大福木の幹回り別の内訳

\begin{tabular}{|c|r|r|r|r|}
\hline 幹回り & $\begin{array}{l}100 \mathrm{~cm} \text { 以上 } \\
200 \mathrm{~cm} \text { 未満 }\end{array}$ & $\begin{array}{r}200 \mathrm{~cm} \text { 以上 } \\
300 \mathrm{~cm} \text { 未満 }\end{array}$ & $\begin{array}{l}300 \mathrm{~cm} \\
\text { 以上 }\end{array}$ & 合計 \\
\hline 今帰仁原 & 417 & 7 & 1 & 425 \\
& $98.1 \%$ & $1.7 \%$ & $0.2 \%$ & $100.0 \%$ \\
\hline 親泊原 & 563 & 29 & 3 & 595 \\
& $94.6 \%$ & $4.9 \%$ & $0.5 \%$ & $100.0 \%$ \\
\hline 今泊 & 980 & 36 & 4 & 1.020 \\
\hline & $96.1 \%$ & $3.5 \%$ & $0.4 \%$ & $100.0 \%$ \\
\hline
\end{tabular}




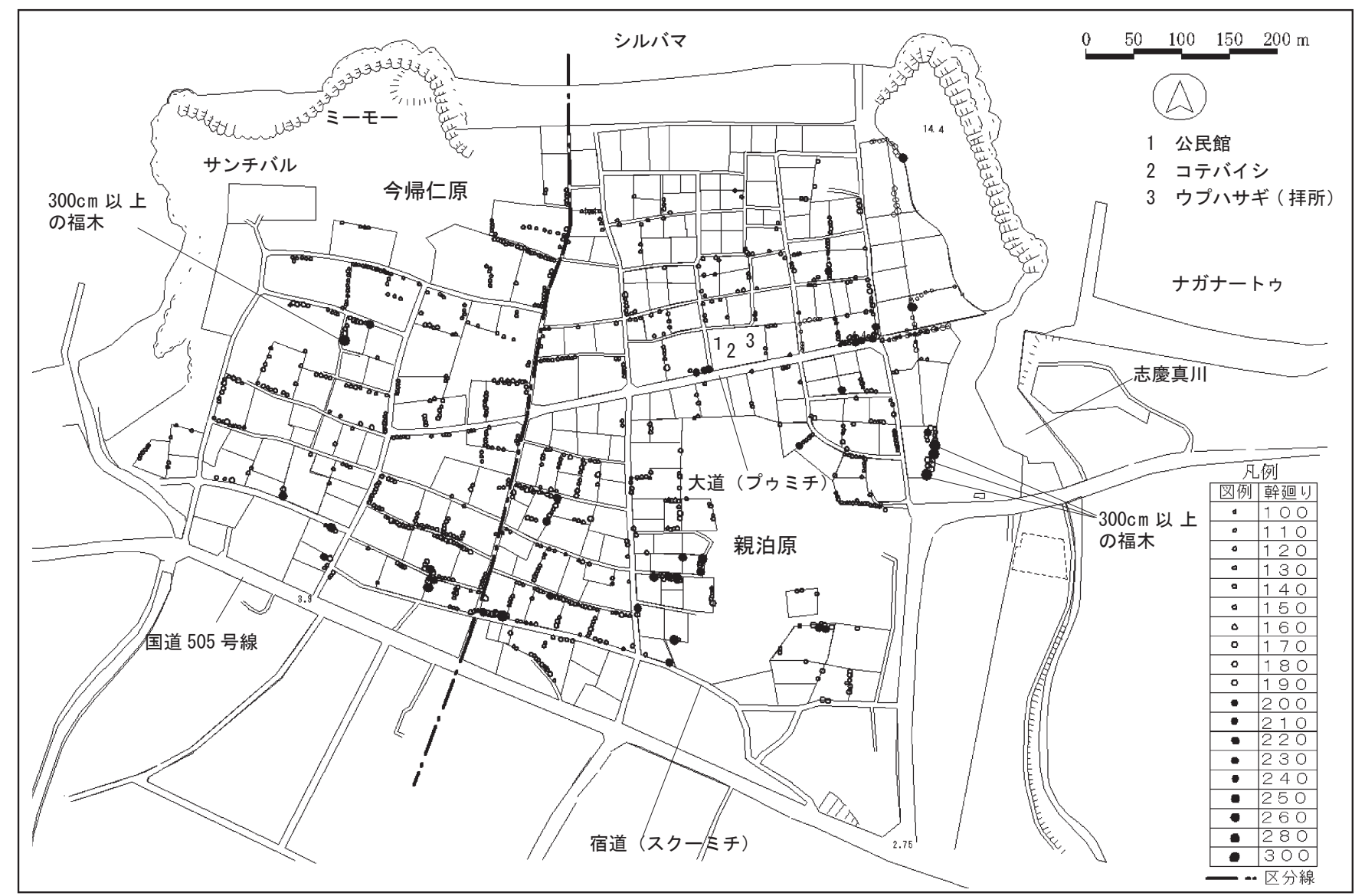

図 3 今泊集落の幹回り $100 \mathrm{~cm}$ 以上の大福木の分布

$300 \mathrm{~cm}$ 未満、 $100 \mathrm{~cm}$ 以上 $200 \mathrm{~cm}$ 未満に 3 区分し、集落形成の歴史との 関係を見ていく。

幹回り $100 \mathrm{~cm}$ 以上の大福木は全部で 1,020 本（全体の $10.3 \%$ ) あ り（表 9)、その内訳は幹回り $300 \mathrm{~cm}$ 以上が 4 本（大福木の $0.4 \%$ )、 幹回り $200 \mathrm{~cm}$ 以上 $300 \mathrm{~cm}$ 未満が 36 本 (同 $3.5 \%$ )、幹回り $100 \mathrm{~cm}$ 以上 $200 \mathrm{~cm}$ 未満が 980 本 (同 $96.1 \%$ ) となる (表 10)。

金武観音寺境内の大福木（幹回り $280 \mathrm{~cm}$ 、樹高 $12 \mathrm{~m}$ 、推定樹齢約 350 年）よりも太い幹回り $300 \mathrm{~cm}$ 以上の大福木は、3 本が親泊原地区 に、1 本が今帰仁原地区に立地している注22)。親泊原地区の 3 本は、 志慶真 (しげま) 川の河口を望む小高い丘の上に並んでいる (図 3)。 琉球王国時代、集落の東端を流れる志慶真川河口には今帰仁城へと

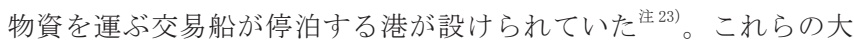
福木は、港への目印としてか、港方向からの風を防ぐ目的で植樹さ れたものと考えられる。今帰仁原地区の 1 本は、最古の屋敷跡とさ れるミーモーとサンチバルのすぐ南側に立地している注24)。

幹回り $200 \mathrm{~cm}$ 以上 $300 \mathrm{~cm}$ 未満の大福木は、今帰仁原地区に 7 本、 親泊原地区に 29 本が立地しており、親泊原地区一の偏りが見られる (表 10)。特に、宿道 (スクーミチ) や馬場跡である大道 (プウミチ) の沿線と宿道と大道を結ぶ筋道 (スージ) 沿いの区画に集中してい る(図 3)。『今帰仁村誌』によると、琉球王国時代には集落南端を 走る国道 505 号線の一本北側の宿道が、番所間を結ぶ主要道路だっ たとある注25)。港から西へ集落の中央を抜ける大道沿いにはウプ八 サギ ( 拝所) や樹齢 300 年以上と言われるコバテイシの大木 ( 県指 定天然記念物）が残っており、現在でも集落の中心となっている。

幹回り $100 \mathrm{~cm}$ 以上 $200 \mathrm{~cm}$ 未満の大福木は、親泊原地区北端の臨海
部を除く集落のほぼ全域に分布している（図 3)。地区別では、今帰 仁原地区 417 本、親泊原地区 563 本となり、分布にさほど大きな差 は見られない（表 10)。幹回り $100 \mathrm{~cm}$ 以上の大福木が見られない区 画は、沖縄県設置以降に開発された比較的新しい区画であろう。

大福木の分布から今泊集落の形成過程を推測すると、地割土地制 度の導入以前から志慶真川近辺やサンチバル南側の旧集落地区で福 木の植樹が始まるが限定的であり、地割土地制度の導入に伴い基盤 状の道路構成による集落の拡大と屋敷林としての福木の植樹が平行 して進められ、現在見られるような集落景観が形成されたものと考 えられる。また、 $100 \mathrm{~cm}$ 末満の幹回りの福木が全体の $89.7 \%$ を占め ることから (表 9)、今泊集落では沖縄県設置以降も継続して屋敷林 の維持管理が行なわれてきたことが分かる。

\section{3. 渡名喜島渡名喜集落における福木屋敷林の実態}

渡名喜島は那覇市の北西約 $58 \mathrm{~km}$ の洋上に位置しており、面積約 3.5 $\mathrm{km}^{2}$ 、周囲約 $12.5 \mathrm{~km}$ 、人口 531 人 (2005 年国勢調查) の近海離島の 一つである。北に粟国島、南東に慶良間（けらま）列島、西に久米 島を望み、これらの島々のほぼ中央に位置している（図 1)。島の地 形は、北部は緩やかな丘陵地帯、南部は山岳地帯となっており、南 東部は絶壁で海に望む。南北の起伏の間に東、西、南の 3 字 (区) からなる渡名喜集落が位置している（図 4)。漆喰で固めた赤瓦莫き 屋根の木造民家を多く残寸景観が高く評価され、2000 年 5 月に国の 重要伝統的建造物群保存地区に指定された。現地調查は、2008 年 8 月 16 日から 19 日にかけて実施した。 


\section{1 渡名喜集落における福木屋敷林の特徵}

\subsection{1 幹回り別の福木の本数}

集落内の寸べての福木の幹回りを、今泊集落と同じ方法で計測 した注26)。その結果、集落全体 (320 区画) で合計 20,172 本の福木 を確認することができた（表 11）。1 区画あたりの福木の本数は、 63.0 本となる (表 12)。また、福木の幹回り注 27) の構成は、「太い」 $20.2 \%$ 、「中間」 $42.2 \%$ 、「細い」37.6\%となる（表 $13 ） 。$

\section{1.2 屋敷林密度の分布特性}

渡名喜集落全 320 区画の総辺数は 1,280 辺となるが、戸境上の屋 敷林は 167 辺 (13.0\%) に過ぎなかった。このため全体に対する影響 は大きくないと判断し、戸境上の屋敷林を重複してカウントし、屋 敷林密度を算出した ${ }^{\text {注 }}$ (8)

集落全体の平均屋敷林密度は、0.66 となる（表 14）。屋敷林密度 の構成は、高密度辺 $3.3 \%$ 、低密度辺 $58.0 \%$ 、無屋敷林辺 $38.7 \%$ と

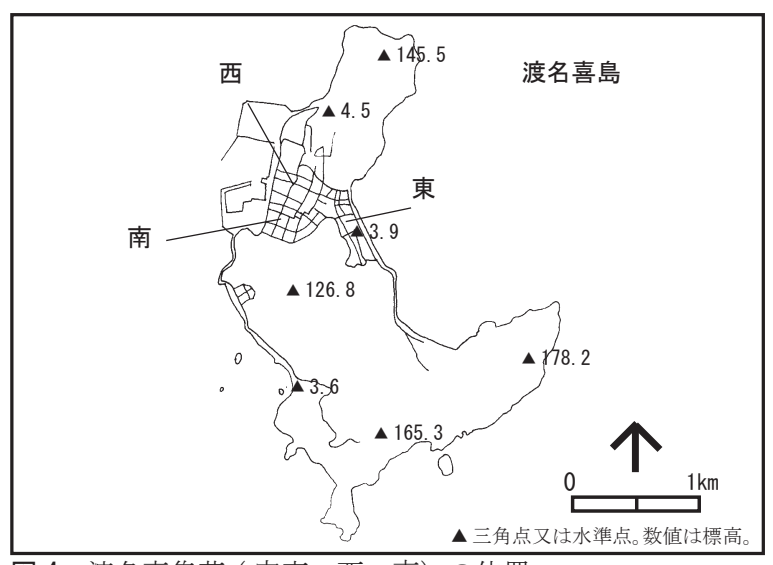

図 4 渡名喜集落（字東、西、南）の位置

表 11 渡名喜集落の幹回り別の福木の本数

\begin{tabular}{|c|c|c|c|c|c|c|c|c|c|c|c|c|c|c|c|c|c|c|c|c|c|c|c|c|c|c|c|c|c|c|c|}
\hline $\begin{array}{c}\text { 幹回り } \\
(\mathrm{cm})\end{array}$ & -20 & $20-30$ & $30-40$ & $40-50$ & $50-60$ & $\begin{array}{c}60-7 \\
0\end{array}$ & $\begin{array}{c}70-8 \\
0\end{array}$ & \begin{tabular}{|l}
$80-$ \\
90
\end{tabular} & $\mid \begin{array}{l}90-1 \\
00\end{array}$ & $\begin{array}{l}100- \\
110\end{array}$ & $\begin{array}{c}110- \\
120\end{array}$ & $\begin{array}{c}120- \\
130\end{array}$ & \begin{tabular}{|c|}
$130-$ \\
140
\end{tabular} & $\mid \begin{array}{c}140- \\
150\end{array}$ & $\begin{array}{l}150- \\
160\end{array}$ & $\mid \begin{array}{c}160- \\
170\end{array}$ & $\begin{array}{c}170- \\
180\end{array}$ & \begin{tabular}{|c|}
$180-$ \\
190
\end{tabular} & $\begin{array}{l}190- \\
200\end{array}$ & $\begin{array}{l}200- \\
210\end{array}$ & $\begin{array}{l}210- \\
220 \\
\end{array}$ & $\mid \begin{array}{c}220- \\
230\end{array}$ & $\begin{array}{l}230- \\
240\end{array}$ & $\begin{array}{c}240- \\
250\end{array}$ & $\begin{array}{l}250- \\
260\end{array}$ & $\mid \begin{array}{c}260- \\
270\end{array}$ & $\mid \begin{array}{l}270- \\
280\end{array}$ & $\begin{array}{l}280- \\
290\end{array}$ & $\mid \begin{array}{c}290- \\
300\end{array}$ & $300-$ & 合計 \\
\hline 字東 & 1,66 & 876 & 774 & & 432 & 393 & 201 & \begin{tabular}{|l|}
201 \\
\end{tabular} & 107 & 66 & 21 & 20 & 16 & 4 & & & 0 & 4 & & & & 0 & & & & & & & & & 5,530 \\
\hline 字西 & 2,844 & 1,44 & 1,030 & 673 & 428 & 318 & 181 & 193 & 119 & 62 & 15 & 16 & & & 5 & 3 & & 4 & & & & 0 & & & & & & & & & 7,356 \\
\hline 字南 & 3,081 & 1,33 & 970 & 670 & 442 & 282 & 165 & 129 & 74 & 69 & 28 & 12 & 15 & 4 & 10 & 2 & 1 & & 0 & & & 0 & 0 & & 0 & & 0 & & & 0 & 7,288 \\
\hline
\end{tabular}

表 12 渡名喜集落の区画あたり福木の本数

\begin{tabular}{|l|r|r|r|}
\hline & \multicolumn{1}{|c|}{ 本数 } & 区画数 & 本数 $/$ 区画 \\
\hline 字東 & 5,530 & 67 & 82.5 \\
\hline 字西 & 7,356 & 144 & 51.1 \\
\hline 字南 & 7,286 & 109 & 66.8 \\
\hline 渡名喜 & 20,172 & 320 & 63.0 \\
\hline
\end{tabular}

表 13 渡名喜集落の幹回り 3 区分別の福木の本数

\begin{tabular}{|c|c|c|c|c|c|c|c|c|c|}
\hline \multicolumn{2}{|r|}{ 幹回り } & \multicolumn{2}{|c|}{ 字東 } & \multicolumn{2}{|c|}{ 字西 } & \multicolumn{2}{|c|}{ 字南 } & \multicolumn{2}{|c|}{ 渡名喜 } \\
\hline い & $50 \mathrm{~cm}$ 以上 & 481 & $26.8 \%$ & 1,362 & $18.5 \%$ & 1,235 & $16.9 \%$ & 4,078 & 20.20 \\
\hline 間 & $\begin{array}{l}20 \mathrm{~cm} \text { 以 } \\
50 \mathrm{~cm} \text { 未 }\end{array}$ & 2,383 & & 150 & $2.8 \%$ & 2,970 & $0.8 \%$ & 3,503 & 2. 20 \\
\hline い & 20cm未満 & 1,666 & $30.1 \%$ & 2,844 & $38.7 \%$ & 3,081 & $42.3 \%$ & 7,591 & 37.60 \\
\hline & 合計 & 5,530 & $100.0 \%$ & 7,356 & $100.0 \%$ & 7,286 & $99.9 \%$ & 20,172 & 100. 0 \\
\hline
\end{tabular}

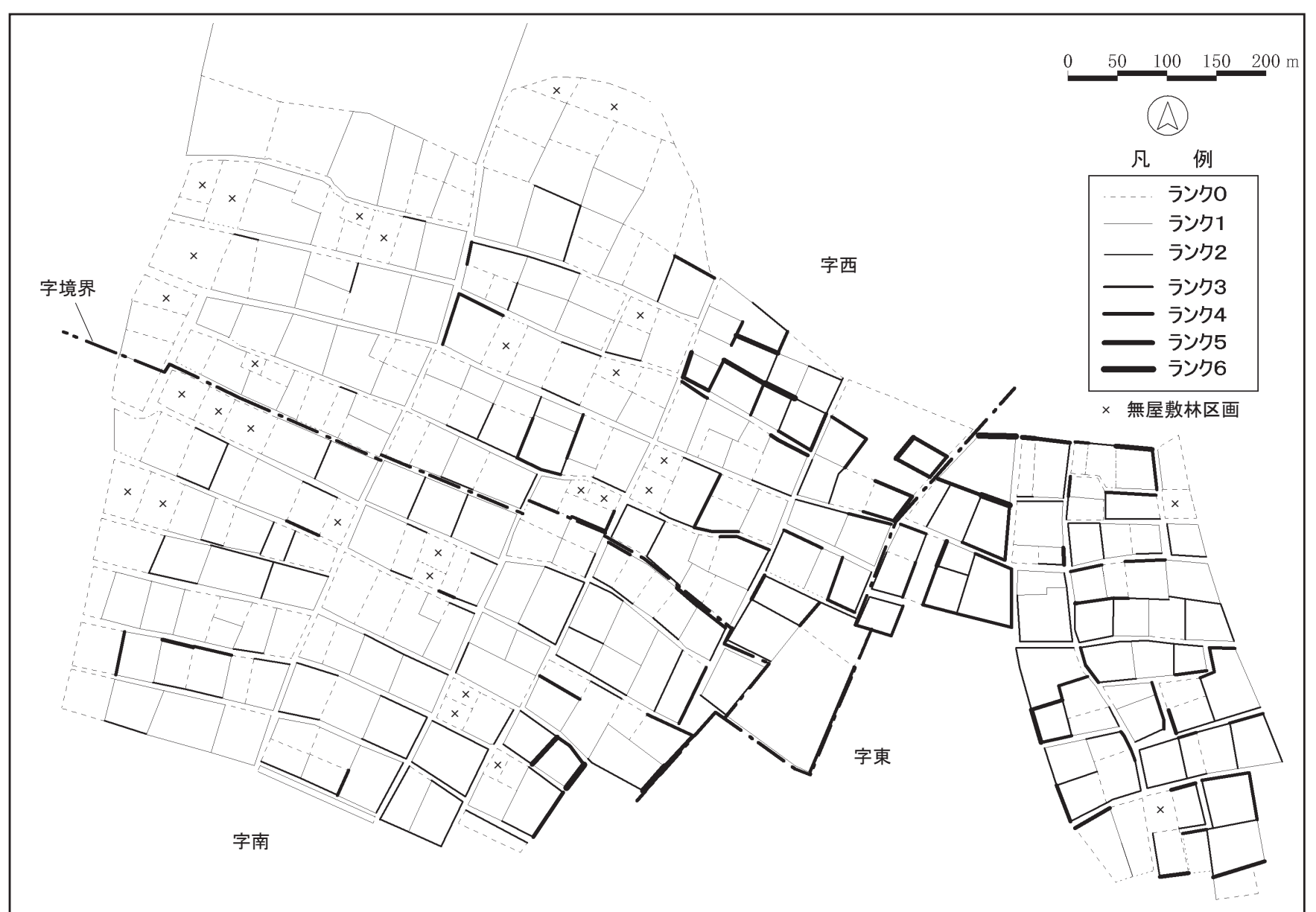

図 5 渡名喜集落の屋敷林密度および無屋敷林区画の分布 
表 14 渡名喜集落の平均屋敷林密度

\begin{tabular}{|l|r|r|r|r|}
\hline & 字東 & 字西 & 字南 & 渡名喜 \\
\hline 東側辺 & 1.07 & 0.55 & 0.68 & 0.70 \\
\hline 西側辺 & 0.94 & 0.46 & 0.31 & 0.51 \\
\hline 南側辺 & 1.19 & 0.51 & 0.61 & 0.68 \\
\hline 北側辺 & 1.49 & 0.55 & 0.63 & 0.75 \\
\hline 全体 & 1.16 & 0.52 & 0.56 & 0.66 \\
\hline
\end{tabular}

表 16 渡名喜集落の無屋敷林区画の状況

\begin{tabular}{|l|r|r|r|}
\hline & 区画数 & $\begin{array}{l}\text { 無屋敷林 } \\
\text { 区無屋敷林 } \\
\text { 区画比率 }\end{array}$ \\
\hline 字東 & 67 & 2 & $3.0 \%$ \\
\hline 字西 & 144 & 14 & $9.7 \%$ \\
\hline 字南 & 109 & 12 & $11.0 \%$ \\
\hline 渡名喜 & 320 & 28 & $8.8 \%$ \\
\hline
\end{tabular}

表 15 渡名喜集落の屋敷林密度の構成

\begin{tabular}{|c|c|c|c|c|c|c|c|c|}
\hline \multirow{3}{*}{ ランク } & 無屋敷林辺 & \multicolumn{3}{|c|}{ 低密度辺 } & \multicolumn{3}{|c|}{ 高密度辺 } & \multirow{3}{*}{ 合計 } \\
\hline & . & 1. & $\ldots 2 \ldots$ & 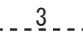 & 4 & $-{ }_{-}^{5} \ldots$ & $\ldots 6$. & \\
\hline & (0) & $\begin{array}{l}\text { (0を超え } \\
\text { て1末満) }\end{array}$ & $\begin{array}{c}\text { (1以上2 } 2 \\
\text { 未満) }\end{array}$ & $\begin{array}{l}\text { (2以上 } \\
3 \text { 未満) }\end{array}$ & $\begin{array}{l}\text { (3以上 } \\
\text { 4末満) }\end{array}$ & $\begin{array}{c}\text { (4以上5 } 5 \\
\text { 未満) }\end{array}$ & (5以上) & \\
\hline \multirow[t]{3}{*}{ 字東 } & \multirow{3}{*}{$\begin{array}{r}68 \\
-25 . \overline{4} \%\end{array}$} & $\begin{array}{r}63 \\
\end{array}$ & 86 & 32 & 13 & & & \multirow{3}{*}{$\frac{268}{100.0 \%}$} \\
\hline & & $23.5 \%$ & $32.1 \%$ & $11.9 \%$ & $4.9 \%$ & $1.5 \%$ & $0.7 \%$ & \\
\hline & & \multicolumn{3}{|c|}{$67.5 \%$} & \multicolumn{3}{|c|}{$7.1 \%$} & \\
\hline \multirow[t]{3}{*}{ 字西 } & 242 & 218 & 71 & 30 & 9 & 4 & 2 & 576 \\
\hline & \multirow{2}{*}{$42.0 \%$} & $37.9 \%$ & $12.3 \%$ & $5.2 \%$ & $1.6 \%$ & $0.7 \%$ & $0.3 \%$ & \multirow{2}{*}{$100.0 \%$} \\
\hline & & \multicolumn{3}{|c|}{$55.4 \%$} & \multicolumn{3}{|c|}{ 2. $6 \%$} & \\
\hline \multirow[t]{3}{*}{ 字南 } & \multirow{3}{*}{$\begin{array}{r}186 \\
-42.7 \%\end{array}$} & 153 & 77 & 12 & 5 & 1 & 2 & \multirow{3}{*}{$\begin{array}{r}436 \\
100.0 \%\end{array}$} \\
\hline & & $35.1 \%$ & $17.7 \%$ & 2. $8 \%$ & 1. $1 \%$ & $0.2 \%$ & $0.5 \%$ & \\
\hline & & \multicolumn{3}{|c|}{$55.5 \%$} & \multicolumn{3}{|c|}{$1.8 \%$} & \\
\hline \multirow{3}{*}{ 渡名喜 } & \multirow{3}{*}{$\begin{array}{r}496 \\
38.7 \%\end{array}$} & 434 & 234 & 74 & 27 & 9 & & \multirow{3}{*}{$\begin{array}{r}1,280 \\
100.0 \%\end{array}$} \\
\hline & & $33.9 \%$ & $18.3 \%$ & $5.8 \%$ & $2.1 \%$ & $0.7 \%$ & $0.5 \%$ & \\
\hline & & \multicolumn{3}{|c|}{$58.0 \%$} & \multicolumn{3}{|c|}{$3.3 \%$} & \\
\hline
\end{tabular}

表 17 渡名喜集落の方位別の屋敷林密度の構成

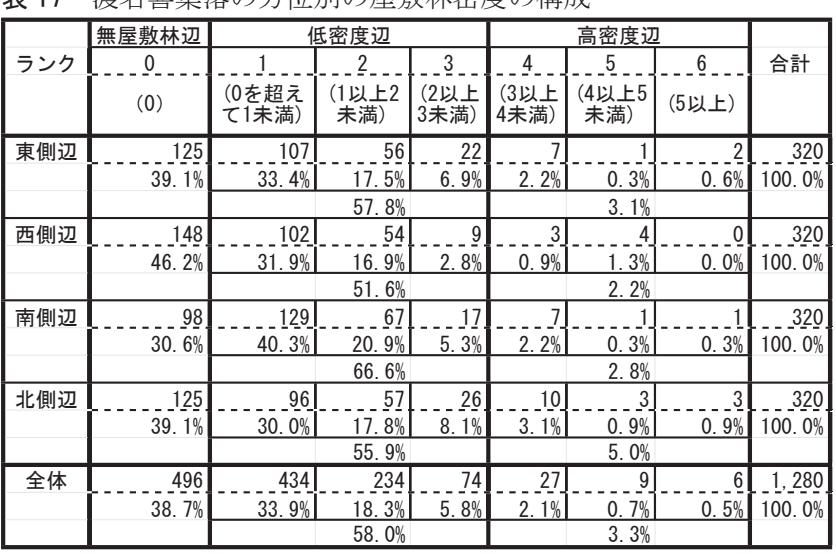

表 18 渡名喜集落の幹回り表 19 渡名喜集落の大福木の幹回り別 $100 \mathrm{~cm}$ 以上の大福木の本数

\begin{tabular}{|c|r|r|r|}
\hline 幹回り & $\begin{array}{c}100 \mathrm{~cm} \\
\text { 未満 }\end{array}$ & $\begin{array}{c}100 \mathrm{~cm} \\
\text { 以上 }\end{array}$ & \multicolumn{1}{c|}{ 合計 } \\
\hline 東字 & 5.383 & .147 & 5.530 \\
& $97.3 \%$ & $2.7 \%$ & $100.0 \%$ \\
\hline 西字 & .7233 & .123 & 7.356 \\
& $98.3 \%$ & $1.7 \%$ & $100.0 \%$ \\
\hline 南字 & 7.143 & .143 & 7.286 \\
& $98.0 \%$ & $2.0 \%$ & $100.0 \%$ \\
\hline 渡名喜 & 19.759 & 413 & 20.172 \\
& $98.0 \%$ & $2.0 \%$ & $100.0 \%$ \\
\hline
\end{tabular}

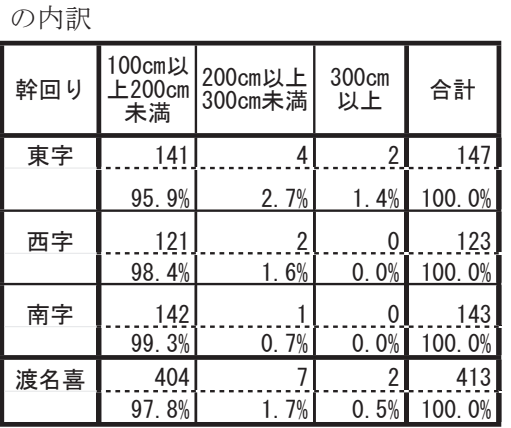

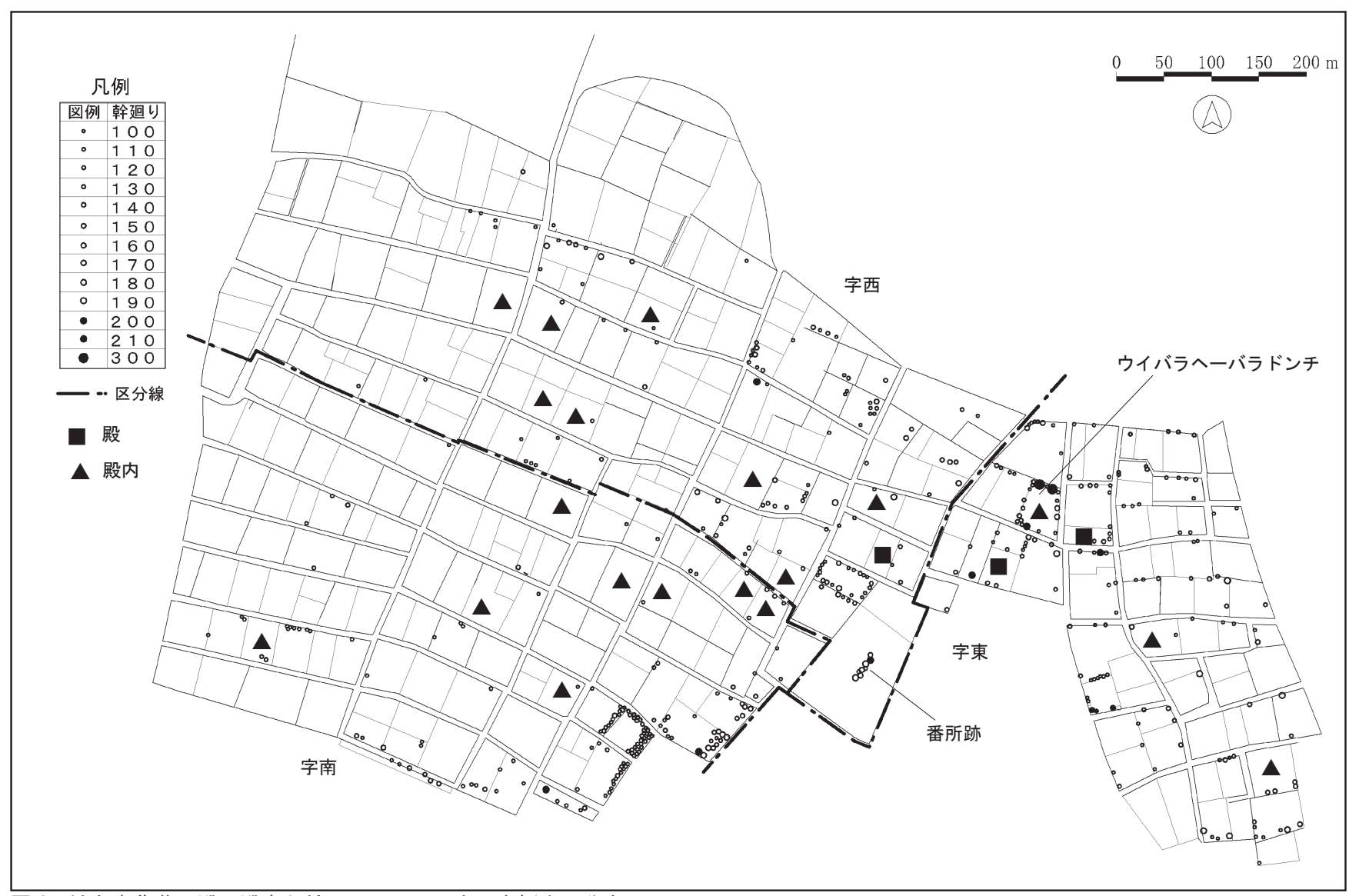

図 6 渡名喜集落の殿・殿内と幹回り $100 \mathrm{~cm}$ 以上の大福木の分布 
なる（表 15）。無屋敷林区画の割合は、全体の $8.8 \%$ となり、今泊集 落よりも 1.6 ポイント低い(表 16)。地区別の無屋敷林区画の割合は、 字東 $3.0 \%$ 、字西 $9.7 \%$ 、字南 $11.0 \%$ となり、字西と字南で高くなっ ている。無屋敷林区画は、字西と字南の西側に多く見られる（図 5)。 集落内の字別の福木の本数は、字東 5,530 本、字西 7, 356 本、字 南 7, 286 本であり、1 区画あたりの本数はそれぞれ、82.5 本、 51.1 本、 66.8 本となる (表 12)。平均屋敷林密度は、字東 (1.16) が字南 (0.56) や字西 (0.52) よりも高く（表 14）、高密度辺の割合も字東 (7. 1\%) で高く、字西 $(2.6 \%)$ や字南 $(1.8 \%)$ では低くなる。無屋敷林辺の割 合は逆に、字南 $(42.7 \%)$ や字西 (42.0\%) が字東 $(25.4 \%)$ よりも高い (表 15)。無屋敷林辺は、無屋敷林区画同様に集落の西側に多い（図 5)。これらのことから、集落発祥の地とされる字東の福木屋敷林は、 他の 2 字よりも充実していることが分かる。

\subsection{3 方位と屋敷林密度の関係}

次に、方位と屋敷林密度の関係を見ていく。渡名喜集落における 方位別の平均屋敷林密度は、高い順に北側 $(0.75)$ 、東側 (0.70)、 南側 (0.68)、西側 (0.51) となる（表 14）。また、方位別の屋敷林 密度の構成を見ると、無屋敷林辺の割合は高い順に西側 (46.2\%)、 東側と北側 $(39.1 \%)$ 、南側 $(30.6 \%)$ となり、高密度辺の割合は北側 $(5.0 \%)$ 、東側 $(3.1 \%)$ 、南側 $(2.8 \%)$ 、西側 $(2.2 \%)$ の順となる（表 17)。これらのことから、渡名喜集落の福木屋敷林は区画の北側が最 も充実しており、東側がそれに次ぐ構成となっていることが分かる。 渡名喜島には気象庁の測候地点がないため、粟国島のアメダス データ（2006-2008）を参考にすると、5月から 8 月は南よりの風、 10 月から 3 月は北 北東の風が多く、平均風速も冬季の北〜北東の 風の方が高い注29)。また、古川・山田・大塚らは渡名喜島の風環境 の特徴として「南北方向の風は山から吹きおろす強風となり、東西 の風は海上からそのまま集落を吹き好形になる」と述べている 注30)。つまり渡名喜島では、冬期には季節風が北の丘陵地帯から集 落方向に吹き下ろし、台風時には東西方向からも潮風が吹きつける ことになる。渡名喜集落の福木屋敷林の構成は、こうした周辺環境 にうまく対応している。

\section{2 大福木の分布と集落形成の関係}

渡名喜集落もまた、そのほぼ全域が地割土地制度に基づく碁盤状 の道路構成となっている (図 6)。今泊集落と同様に、幹回り $100 \mathrm{~cm}$ 以上の大福木の分布と集落形成の歴史との関係を見ていく。

沖縄県設置以前に植樹されたと考えられる幹回り $100 \mathrm{~cm}$ 以上の大 福木は全部で 413 本（全体の 2. $0 \%$ ） あり（表 18)、その内訳は、幹 回り $300 \mathrm{~cm}$ 以上が 2 本 (大福木の $0.5 \%$ )、幹回り $200 \mathrm{~cm}$ 以上 $300 \mathrm{~cm}$ 未満が 7 本 (同 $1.7 \%$ )、幹回り $100 \mathrm{~cm}$ 以上 $200 \mathrm{~cm}$ 未満が 404 本 (同 97. 8\%) となる (表 19)。

渡名喜集落には幹回り $300 \mathrm{~cm}$ 以上の大福木が 2 本あるが、 2 本共、 字東にあるウイバラヘーバラドンチの区画に立地している。

幹回り $200 \mathrm{~cm}$ 以上 $300 \mathrm{~cm}$ 未満の大福木は、字東に 4 本、字南に 2 本、 字西に 1 本が立地しており、やはりウイバラヘーバラドンチ周辺に 集中している（図 6)。ウイバラヘーバラドンチの周辺にはやや不整 然な区画割りが見られ、地割土地制度の導入以前から集落が形成さ れていた旧集落地区であると思われる。

幹回り $100 \mathrm{~cm}$ 以上 $200 \mathrm{~cm}$ 未満の大福木は、集落西側を除くほぼ全 域に分布している（図 6)。『渡名喜村史』注31)により、祭祀場とし
て使われる殿 (ドン、トン) と琉球王朝から役職を与えられたとさ れる旧家の屋号である殿内 (ドンチ) の位置を確認した。殿は字東 に 2 ケ所、字西に 1 ケ所の合計 3 ケ所、殿内は字東に 3 ケ所、字西 に 8 ヶ所、字南に 8 ケ所の合計 19 ヶ所あった。幹回り $100 \mathrm{~cm}$ 以上 $200 \mathrm{~cm}$ 未満の大福木の分布と殿、殿内の位置関係を見ると、字東に 位置するすべての殿・殿内に分布が見られたが、字西の殿 1 ケ所と 字西と字南の殿内の半数弱には分布は見られなかった。大福木が見 られないこれらの殿内は、近年の分家により屋号に殿内が加えられ たものであろう。こうした大福木の分布は、周辺の丘陵地（サ卜） から居住地が字東に移り、その後、字西、字南へと拡大していった との渡名喜集落形成に関する伝承を裏付けるものである注 322

大福木の分布から渡名喜集落の形成過程を推測すると、地割土地 制度の導入以前からウイバラヘーバラドンチを中心に旧集落地区で 福木の植樹が始まるが限定的であり、地割土地制度の導入に伴い碁 盤状の道路構成による集落の拡大と屋敷林としての福木の植樹が平

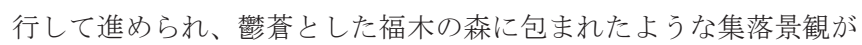
形作られて行ったものと考えられる。さらに、 $100 \mathrm{~cm}$ 未満の幹回り の福木が $98.0 \%$ を占めることから（表 18）、渡名喜集落の福木は、 その大半が沖縄県設置以降に植樹されたものであることが分かる。

\section{4. 沖縄島北部集落と近海離島集落の福木屋敷林の比較}

福木の総本数は多い順に、渡名喜集落 20,172 本、備瀬集落 18,143 本、今泊集落 9, 904 本、粟国島東・西集落 9, 796 本となり、区画あた り本数は多い順に、備瀬集落 65.5 本、渡名喜集落 63.0 本、今泊集 落 38.1 本、粟国島東・西集落 14.1 本となる (表 20)。総本数、区画 あたり本数共に、渡名喜集落と備瀬集落における多さが顕著である。

福木の幹回りの分布を見ると、「太い」の割合は多い順に、粟国島 東・西集落 $57.6 \%$ 、備瀬集落 $36.2 \%$ 、今泊集落 $31.7 \%$ 、渡名喜集 落 $20.2 \%$ となり、「細い」の割合は多い順に、渡名喜集落 $37.6 \%$ 、 今泊集落 $32.1 \%$ 、備瀬集落 $24.7 \%$ 、栗国島東・西集落 $10.4 \%$ とな る（表 21）。幹回り $100 \mathrm{~cm}$ 以上の大福木の割合は、粟国島東・西集 落 $13.0 \%$ 、今泊集落 $10.3 \%$ 、渡名喜集落 $2.0 \%$ 、備瀬集落 $1.7 \%$ と なり、粟国島東・西集落と今泊集落における割合が高い（表 22）。 幹回り $100 \mathrm{~cm}$ 以上の大福木の本数を見ると、栗国島東・西集落 1,275 本、今泊集落 1,020 本となり、これはそれぞれ備瀬集落の 4.0 倍と 3.2 倍、渡名喜集落の 3.2 倍と 2.5 倍の多さとなる。これらのことから、 粟国島東・西集落と今泊集落には古くて立派な福木が多数生育して いることが分かる。また、福木の幹回りの分布から、備瀬集落と渡 名喜集落の福木は、その大半が沖縄県設置以降に植樹されたものと 考えられる。

無屋敷林区画の割合は、備瀬集落 $19.1 \%$ 、粟国島東・西集落 $17.6 \%$ 、今泊集落 $10.4 \%$ 、渡名喜集落 $8.8 \%$ となり（表 23 )、無屋敷 林辺の割合は、粟国島東・西集落 $55.2 \%$ 、今泊集落 $42.0 \%$ 、渡名喜 集落 $38.7 \%$ 、備瀬集落 $37.7 \%$ となる（表 24 )。無屋敷林区画の割合 が高いのは備瀬集落と粟国島東・西集落であるが、備瀬集落では無 屋敷林辺の割合は低くなっている。これは、無屋敷林区画が新しく 開発された集落外縁部に集中しており、それ以外の区画では無屋敷 林辺が少ないためである。これに対して、粟国島東・西集落では無 屋敷林辺の割合も高く、集落の全域に無屋敷林辺が広がっている。 渡名喜集落では無屋敷林区画と無屋敷林辺の割合が共に低く、4 集 
落の中で最も満遍なく集落内に福木が分布している。今泊集落の福 木屋敷林の分布は、粟国島東・西集落と渡名喜集落の中間的な性格 となっている。

福木屋敷林の特徵が最も類似しているのは、沖縄島北部の備瀬集 落と近海離島の渡名喜集落である。両集落共に、幹回りの「細い」 福木の割合が多く大福木は少ないが、福木の総本数と区画あたり本

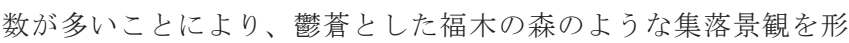
作っている。ただし、備瀬集落の外縁部には、福木が生育していな い新集落も見られる。

粟国島東・西集落の福木屋敷林の特徵は、集落全域に無屋敷林辺 が多く見られる上、福木の総本数と区画あたり本数が少ないことで ある。このため、屋敷林としての広がりに欠け、まばらに分布して いる印象を与える。しかし、福木の幹回りの構成を見ると、幹回り が「太い」福木の割合と幹回りが $100 \mathrm{~cm}$ を超える大福木の割合が 4 集落の中で最も高く、古く立派な福木が多く生育している。

今泊集落の福木の幹回りの構成は、「太い」、細い」の割合共に備 瀬集落と渡名喜集落の中間となっている。集落内には大福木も多く 見られるが、総本数や区画あたり本数が少ない上に屋敷林としての 広がりが限定的であるため、備瀬集落や渡名喜集落よりも景観的な 印象が薄い。

福木の幹回りを詳細に計測した粟国島東・西集落、今泊集落、渡 名喜集落の 3 集落において、屋敷林密度が最も高いのは区画の北側 辺であった。簡便な計測法を用いた備瀬集落においても、北側辺の 屋敷林が最も充実していることが分かっている注33)。こうした屋敷 構えは、冬期の季節風対策として有効であるばかりでなく、夏期の 高温多湿の気候条件から屋敷内に南の風を取り入れることが配慮さ れる沖縄の伝統民家の屋敷配置にも適合している ${ }^{\text {注 } 34) 。 ~}$

北側の次に充実しているのは、粟国島東・西集落、渡名喜集落、 今泊集落は東側 (今泊は西側と僅差)、備瀬集落は西側となる。各 集落から最寄りの海の方角は、栗国島東・西集落は南、渡名喜集落 は東と西、今泊集落は北 (および東と西)、備瀬集落は西 (および北) となる。屋敷林が最も充実している北側に海があるのは今泊集落の
みである。備瀬集落と渡名喜集落では、北側の次に屋敷林が充実し ている方位と最寄りの海の方角が一致している。海岸線から $500 \mathrm{~m}$ ほ ど離れた海抜 $40 \mathrm{~m}$ の高台に位置する粟国島東・西集落では、2 番目 に屋敷林が充実している方位と海の方角は一致していない。

今泊集落と渡名喜集落では、幹回り $300 \mathrm{~cm}$ 以上の大福木は集落発 祥の地とされている区画の周辺に立地していた。幹回り $200 \mathrm{~cm}$ 以上 $300 \mathrm{~cm}$ 未満の大福木は、いずれの集落においても集落発祥の地の周 辺や旧道沿いに多く立地していた。幹回り $100 \mathrm{~cm}$ 以上 $200 \mathrm{~cm}$ 未満の 大福木は、地割土地制度に基づき築かれた碁盤状の道路構成の集落 全域に分布しており、集落の拡大と平行して屋敷林としての福木の 植栽が進められたことが分かる。また、各集落には幹回り $100 \mathrm{~cm}$ 未 満の福木も多く生育していることから、沖縄県設置以降も福木の植 樹や屋敷林の維持管理が続けられてきたことも分かった。

5. まとめ

4 集落（備瀬集落、今泊集落、粟国島東・西集落、渡名喜集落） の比較を通じて、福木屋敷林の地域特性について以下のことが明ら かになった。

第一に、集落の地理的な近さが必ずしも福木屋敷林の特徵の類似 に結びつかないことが分かった。調查対象とした 4 集落の内、福木 屋敷林の特徵が最も似ていたのは沖縄島北部の備瀬集落と近海離島 の渡名喜集落だった。これらの集落の屋敷林には、幹回りの「細い」 福木の割合が多く幹回り $100 \mathrm{~cm}$ 以上の大福木は少ないが、福木の総

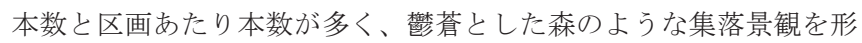
作っている。一方、渡名喜集落と同じ近海離島の栗国島東・西集落 では、集落全域に無屋敷林辺が多く見られる上、福木の総本数と区 画あたり本数が少ない。このため、集落景観としてのインパクトに はやや欠けるが、 4 集落の中で幹回り $100 \mathrm{~cm}$ 以上の大福木の本数が 最も多く、古く立派な福木が多く生育している。今泊集落の福木屋 敷林の特徴はその中間的な性格にあり、集落内における屋敷林の分 布状況は栗国島東・西集落と渡名喜集落 の中間、福木の幹回り別 構成における「太い」と「細い」の割合は備瀬集落と渡名喜集落の
表 20 区画あたりの福木の本数の比較

\begin{tabular}{|l|r|r|r|}
\hline \multicolumn{1}{|c|}{ 集落名 } & \multicolumn{1}{c|}{ 本数 } & 区画数 & 本数 $/$ 区画 \\
\hline 備瀬 & 18,143 & 277 & 65.5 \\
\hline 今泊 & 9,904 & 260 & 38.1 \\
\hline 㔄国島東・西 & 9,796 & 697 & 14.1 \\
\hline 渡名喜 & 20,172 & 320 & 63.0 \\
\hline
\end{tabular}

表 22 幹回り $100 \mathrm{~cm}$ 以上の大福木の本数の比較

\begin{tabular}{|c|c|c|c|}
\hline 幹回り & $100 \mathrm{~cm}$ 未満 & $100 \mathrm{~cm}$ 以上 & 合計 \\
\hline \multirow[t]{2}{*}{ 備瀬 } & 17,827 & 316 & 18,143 \\
\hline & $98.3 \%$ & $1.7 \%$ & $100.0 \%$ \\
\hline \multirow[t]{2}{*}{ 今泊 } & 8,884 & 1,020 & 9,904 \\
\hline & $89.7 \%$ & 10. $3 \%$ & $100.0 \%$ \\
\hline \multirow{2}{*}{$\begin{array}{l}\text { 粟国島 } \\
\text { 西 }\end{array}$} & 8,521 & 1,275 & 9,796 \\
\hline & $87.0 \%$ & $13.0 \%$ & $100.0 \%$ \\
\hline \multirow[t]{2}{*}{ 渡名喜 } & 19,759 &. .413 & 20,172 \\
\hline & 98. $0 \%$ & 2. $0 \%$ & $100.0 \%$ \\
\hline
\end{tabular}

表 23 無屋敷林区画の比較

\begin{tabular}{|l|r|r|r|}
\hline \multicolumn{1}{|c|}{ 青落名 } & 区画数 & 無屋敷林区画数 & 無屋敷林区画比率 \\
\hline 備瀬 & 277 & 53 & $19.1 \%$ \\
\hline 今泊 & 260 & 27 & $10.4 \%$ \\
\hline 粟国島東・西 & 697 & 123 & $17.6 \%$ \\
\hline 渡名喜 & 320 & 28 & $8.8 \%$ \\
\hline
\end{tabular}

表 21 幹回り 3 区分別の福木の本数の比較

\begin{tabular}{|c|c|c|c|c|c|c|c|c|c|}
\hline \multicolumn{2}{|r|}{ 幹回り } & \multicolumn{2}{|c|}{ 備瀬 } & \multicolumn{2}{|c|}{ 今泊 } & \multicolumn{2}{|c|}{ 粟国島東·西 } & \multicolumn{2}{|c|}{ 渡名喜 } \\
\hline 太い & $50 \mathrm{~cm}$ 以上 & 6,565 & $36.2 \%$ & 3,137 & $31.7 \%$ & 5,645 & $57.6 \%$ & 4,078 & $20.2 \%$ \\
\hline 中間 & $20 \mathrm{~cm}$ 以上 $50 \mathrm{~cm}$ 未満 & 7,089 & $39.1 \%$ & 3,582 & $36.2 \%$ & 3,133 & $32.0 \%$ & 8,503 & 42. $2 \%$ \\
\hline 細い & $20 \mathrm{~cm}$ 未満 & 4,489 & $24.7 \%$ & 3,185 & $32.1 \%$ & 1,018 & $10.4 \%$ & 7,591 & $37.6 \%$ \\
\hline & 合計 & 18,143 & $100.0 \%$ & 9,904 & $100.0 \%$ & 9,796 & $100.0 \%$ & 20,172 & $100.0 \%$ \\
\hline
\end{tabular}

表 24 屋敷林密度の構成の比較

\begin{tabular}{|c|c|c|c|c|c|c|c|c|}
\hline \multirow{3}{*}{ ランク } & 無屋敷林辺 & \multicolumn{3}{|c|}{ 低密度辺 } & \multicolumn{3}{|c|}{ 高密度辺 } & \multirow{3}{*}{ 合計 } \\
\hline & . 0 & 1. & . 2 & 3 & -4 & 5 & 6 & \\
\hline & (0) & $\begin{array}{l}\text { (0を超え } \\
\text { て1未満) }\end{array}$ & $\begin{array}{c}\text { (1以上2 } \\
\text { 未満) }\end{array}$ & $\begin{array}{l}\text { (2以上 } \\
\text { 3末満) }\end{array}$ & $\begin{array}{l}\text { (3以上 } \\
\text { 4末満) }\end{array}$ & $\begin{array}{c}\text { (4以上5 } \\
\text { 未満) }\end{array}$ & (5以上) & \\
\hline \multirow{3}{*}{ 備瀬 } & 418 & 165 & 174 & 157 & 78 & 63 & 53 & 1,108 \\
\hline & \multirow[t]{2}{*}{$37.7 \%$} & 14. $9 \%$ & $15.7 \%$ & 14. $2 \%$ & $7.0 \%$ & $5.7 \%$ & $4.8 \%$ & \multirow[t]{2}{*}{$100.0 \%$} \\
\hline & & \multicolumn{3}{|c|}{$44.8 \%$} & \multicolumn{3}{|c|}{$17.5 \%$} & \\
\hline \multirow{3}{*}{ 今泊 } & \multirow{3}{*}{$\begin{array}{r}-437 \\
-42.0 \% \\
\end{array}$} & 231 & 165 & 98 & 64 & 19 & 26 & 1,040 \\
\hline & & $22.2 \%$ & $15.9 \%$ & $9.4 \%$ & $6.2 \%$ & $1.8 \%$ & $2.5 \%$ & \multirow[t]{2}{*}{$100.0 \%$} \\
\hline & & \multicolumn{3}{|c|}{$47.5 \%$} & \multicolumn{3}{|c|}{$10.5 \%$} & \\
\hline \multirow{3}{*}{$\begin{array}{l}\text { 粟国島 } \\
\text { 東·西 }\end{array}$} & \multirow{3}{*}{$\begin{array}{l}1,537 \\
-55.2 \%\end{array}$} & 432 & _ 347 & 187 & 138 & $\ldots 66$ & & 2,782 \\
\hline & & $15.5 \%$ & $12.5 \%$ & $6.7 \%$ & $5.0 \%$ & $2.4 \%$ & $2.7 \%$ & \multirow{2}{*}{$100.0 \%$} \\
\hline & & \multicolumn{3}{|c|}{$34.7 \%$} & \multicolumn{3}{|c|}{$10.1 \%$} & \\
\hline \multirow{3}{*}{ 渡名喜 } & \multirow{3}{*}{$\begin{array}{r}-496 \\
-38.7 \%\end{array}$} & 434 & . $23 \underline{3}$ & $\begin{array}{r}74 \\
-.1\end{array}$ & 27 & $\ldots 9$ & 6 & \multirow{3}{*}{$100.0 \%$} \\
\hline & & $33.9 \%$ & $18.3 \%$ & $5.8 \%$ & 2. $1 \%$ & $0.7 \%$ & $0.5 \%$ & \\
\hline & & \multicolumn{3}{|c|}{$58.0 \%$} & \multicolumn{3}{|c|}{$3.3 \%$} & \\
\hline
\end{tabular}


中間となっている。

第二に、福木屋敷林の構成は、周辺環境にうまく対応したもので あることが分かった。沖縄島北部と近海離島の別なく、4 集落す心゙ ての福木屋敷林において北側辺が最も充実しており、冬場の季節風 対策を第一義とした構えとなっている。また、海に隣接した低地に 位置する備瀬集落と渡名喜集落では、北側の次に屋敷林が充実して いる方位と最寄りの海の方角が一致しており、防風・防潮林として の役割も重視されている。しかし、海岸線から500m ほど離れた海抜 $40 \mathrm{~m}$ の高台に位置する粟国島東・西集落では、2 番目に屋敷林が充実 している方位と海の方角は一致しなかった。今泊集落では、屋敷林 が最も充実している北側に海が位置している。

第三に、4 集落すべてにおいて、沖縄県設置以前に植樹されたと 考えられる幹回り $100 \mathrm{~cm}$ 以上の大福木の分布から集落の形成過程を たどることができた。今泊集落と渡名喜集落では、幹回り $300 \mathrm{~cm}$ 以 上の大福木は集落発祥の地とされている区画の周辺に立地してい た。幹回り $200 \mathrm{~cm}$ 以上 $300 \mathrm{~cm}$ 未満の大福木は、いずれの集落におい ても、集落発祥の地の周辺や旧道沿いに多く立地していた。幹回り $100 \mathrm{~cm}$ 以上 $200 \mathrm{~cm}$ 未満の大福木は、地割土地制度に基づき築かれた 碁盤状の道路構成の集落全域に分布しており、集落の拡大と平行し て屋敷林としての福木の植栽が進められたことが分かった。また、 各集落には幹回り $100 \mathrm{~cm}$ 未満の福木も多く生育していることから、 沖縄県設置以降も福木の植樹や屋敷林の維持管理が続けられてきた ことも分かった。

栗国島東・西集落や今泊集落の福木屋敷林は、これまで観光地と して有名な備瀬集落や伝統的建造物群保存地区に指定された渡名喜 集落の陰に隠れてあまり注目されてこなかった。しかし、両集落に は、希少な大福木が多数生育している。4 集落の比較を通して解明 された福木屋敷林の地域特性が広く一般に認知されることにより、 個々の集落の福木屋敷林の文化的価值が再認識され、長期的な維持 管理体制の確保のための一助となれば幸いである。

\section{謝辞}

本研究は、平成 20 年度科学研究費補助金 (萌芽研究) の助成を受 けました。また、調查作業にあたり、琉球大学工学部環境建設工学 科安藤研究室（当時）の 4 年生および修士課程の皆さんの協力を得 ました。記して謝意を表します。

\section{注}

注 1）福木はオトギリソウ科に属する雌雄異種の常緑高木で、樹高 20 メート ル、樹径 80 センチに達する。直幹性が強く地際から頂部まで葉が密生 し、防風、防潮、防砂、防火などに効果がある。環境而性に極めて富み、 脱水症状で落葉することがない。

注 2）仲松弥秀、古層の村：沖縄民俗文化論、沖縄夕イムス社、1977、94-95 頁参照。また、琉球王朝は「家屋制限令」により、赤瓦の使用を制限し ていたため、農村部の家屋は茅屋根が基本であり、周囲を石垣や屋敷林 で固めなければ台風や冬の季節風をしのぐことは困難であった。

注 3）拙稿の安藤徹哉、小野啓子: 沖縄島中北部集落における屋敷林の変化に 関する研究 - 三時点 (1945、1972-74、2003 年) の空中写真の比較と聞 き取りを通して一、日本建築学会計画系論文集、第 630 号、1723-1728 頁、 2008 を参照。

注 4) 拙稿の安藤徹哉、小野啓子：沖縄島本部町備瀬集落における福木屋敷林 の実態、日本建築学会計画系論文集、第 630 号、1729-1733 頁、2008 を 参照

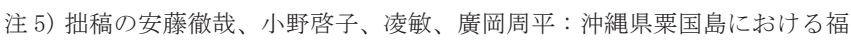

木屋敷林の実態、日本建築学会計画系論文集、第 649 号、603-608 頁、 2010 を参照。

注 6) やまびこの会編：沖縄のフクギ（福木）屋敷林を考える、沖縄緑化推進 委員会、2006.

注 7) 今泊誌編集委員会編 : 今泊誌、1994.

注 8） 今帰仁村教育委員会編：今帰仁村文化財調查報告書第 25 集 今帰仁城 跡発掘調查報告 III、2008 年 3 月. 高橋誠一、松井幸一、松井僚平によ る「第VI章 今泊の集落景観と保全」の章に家屋と屋敷囲いの調查結 果がまとめられている (57-81 頁)。

注 9）古川修文・山田水城・大塚信哉：沖縄・渡名喜島における集落の風性 状について：その 1 実測調查による解析、日本建築学会大会学術講演 梗概集 E、147-148 頁、1985.

注 10）古川修文・山田水城・大塚信哉：沖縄・渡名喜島における集落の風性 状について：その 2 風洞実験のよる解析、日本建築学会大会学術講演 梗概集 E、149-150 頁、1985.

注 11）渡名喜島調查委員会編: 沖縄渡名喜島における言語・文化の総合的研究、 法政大学沖縄文化研究所、1991.

注 12）神末憲一・森田大・渡嘉敷健：沖縄の小離島における防風植栽空間に 関する考察、日本建築学会大会学術講演梗概集 D-1、973-974 頁、1996.

注 13) 大石結奈、大戸慎二 : 小離島におけるフクギ屋敷林の環境特性に関す る研究、平成 7 年度琉球大学卒業研究、 1996 .

注 14）漆原和子・ 乙幡康之：沖縄県渡名喜島における屋敷囲いの特色とその 変遷、季刊地理学 59(2)、99-110 頁、2007.

注 15）前掲注 7）の今泊誌編集委員会編（1994）,12 頁および 48-50 頁参照。

注 16) 一本のひもを準備し、片端に結び目を付ける。その結び目から $10 \mathrm{~cm}$ 刻 みで結び目を付ける。胸の高さでこのひもを福木に巻き付け、幹回りを 測定した。

注 17）生育環境が異なり、福木の個体差もあるが、沖縄島南部の知念城址の 福木の切り株では $1 \mathrm{~cm}$ あたりの年輪数は 8 本であった（前掲注 6) のや まびこの会 $(2006) 、 46$ 頁参照)。幹回りを $\mathrm{y}(\mathrm{cm})$, 半径を $\mathrm{r}(\mathrm{cm}) 、$ 円周 率を $\pi$ とすると、推定樹齢 $\mathrm{x}$ (年) は以下の式で算出される。 $\mathrm{r}=\mathrm{y} /(2 \pi)$

$\mathrm{x}=8 \mathrm{r}$ 幹回り $50 \mathrm{~cm}$ の福木の推定樹齢はおよそ 64 年となり、ほぼ沖縄戦前後の ものとなる。また、幹回り $20 \mathrm{~cm}$ の福木の推定樹齢はおよそ 25 年となる。

注 18) 福木の幹回りを $\mathrm{y}(\mathrm{cm})$ 、半径を $\mathrm{r}(\mathrm{cm})$ 、幹の断面積を $\mathrm{A}(\mathrm{cm} 2)$ 、敷地一辺 あたりの福木の断面積の和を $\Sigma \mathrm{A}(\mathrm{cm} 2)$ 、敷地の一辺の長さを $\mathrm{L}(\mathrm{cm}) 、 円$ 周率を $\pi$ とすると、福木の屋敷林密度 $\mathrm{D}(\mathrm{cm})$ は以下の式で表される。 $\mathrm{R}=\mathrm{y} /(2 \pi)$

$\mathrm{A}=\mathrm{r} 2 \pi$ $\mathrm{D}=(\Sigma \mathrm{A}) / \mathrm{L}$

注 19）前掲注 2）の仲松（1977、111-131 頁）によると、一種の班田制である 地割土地制度は 1737 年に導入され、それ以降の移動・新設村落や分家 地域が碁盤状の形態を取るようになった。

注 20）樹齢の算出式については、注 17）を参照。

注 21) 1872 年の琉球藩設置から 1879 年の沖縄県設置までを琉球処分と言う。 これにより琉球王国は消滅した。なお、地割土地制度は1903 年までに 廃止された。前掲注 2) の仲松（1977、120 頁）参照。

注 22）幹回り $300 \mathrm{~cm}$ の福木の樹齢を推定するとおよそ 395 年となる。

注 23）親泊の親は「大きな」「立派な」を意味し、泊は「港」を意味する。な きじん研究、11 号、今帰仁村歴史文化センター、2002、141 頁参照。

注 24）サンチバルは海風が強く、また水利が悪いため、集落はその南側に移 動したとされる。前掲注 7）の今泊誌編集委員会編（1994）、12 頁参照。 注 25）前掲注 7) 今泊誌編集委員会編（1994）、69-77 頁参照。

注 26）幹回りの計測方法については、前掲注 16）参照。

注 27）推定樹齢については、前掲注 17) 参照。

注 28) 屋敷林密度の計算式については、前掲注 18) 参照。

注 29）前掲注 5）の安藤・小野・凌・廣岡（2010）参照。

注 30）前掲注 9）の古川・山田・大塚（1985、147-148 頁）参照。

注 31）渡名喜村編: 渡名喜村史、上・下巻、1983 のうち、下巻 914-925 頁参照。 注 32）前掲注 31）の渡名喜村（1983）下巻 707 頁参照。

注 33）前掲注 4）の安藤、小野（2008）を参照。

注 34）福島駿介：琉球の住まい-光と影とかたち-、丸善、1993.61 頁参照。 